\title{
LIFE-SPAN OF CORPORA LUTEA IN EWES WITH ONE CONGENITALLY ABSENT UTERINE HORN
}

\author{
G. L. HUNTER * \\ Department of Animal Physiology, College of Agriculture, Stellenbosch, \\ South Africa
}

(Received 17th February 1970, revised 8th May 1970)

It has been postulated that the uterus in the sheep is either directly or indirectly responsible for the regulation of the life-span of the corpus luteum (CL) (see recent reviews by Ginther, 1967; Melampy \& Anderson, 1968; Galdwell, Rowson, Moor \& Hay, 1969). A local relationship between each uterine horn and the adjacent ovary has been suggested, since the lack of one of the uterine horns, achieved by partial (unilateral) hysterectomy, appears to prolong the life-span of CL in the ipsilateral ovary, but has no such effect on CL in the ovary adjacent to the remaining horn (Inskeep \& Butcher, 1966; Moor \& Rowson, 1966). An alternative explanation, suggested by Moor \& Rowson (1966) and emphasized by Nalbandov \& Gook (1968), is that it is the effect of the surgery itself rather than the absence of the uterine horn which prolongs the life of the cL. Recently, however, McCracken \& Caldwell (1969) recorded certain observations on a ewe with a congenitally absent uterine horn which were regarded as providing supporting evidence for the contention that it is the absence of the uterine horn which increases the life-span of CL in the adjacent ovary. The objects of this communication are to draw attention to a deficiency in the evidence recorded by McCracken \& Galdwell (1969) and also to present observations made in this laboratory on two congenitally uni-cornual ewes. These observations do not support the view that there is a significant local relationship between a uterine horn and its adjacent ovary.

McCracken \& Caldwell (1969) based their contentions on the preliminary observations that during a period of almost 2 months no signs of oestrus occurred in the ewe in question, although during the same period the other ewes in the flock were said to have been cycling normally. At the end of the period, the ewe's reproductive tract was excised, the left uterine horn was found to be absent and the left ovary to contain a large cL. McCracken \& Caldwell concluded that the absence of oestrus in this ewe was the result of the persistence of the aL during this period. They did not, however, examine the ovaries of their ewe during the 2 months of apparent sexual inactivity and so did not eliminate the possibility that three, consecutive 'silent ovulations' might have occurred in the animal during this period. Ovulation without oestrus, first recorded by Grant (1933), is not uncommon in the sheep at all stages of the breeding season

\footnotetext{
* Postal address: P.O. Box 3028, Stellenbosch, South Africa.
} 
and three or more consecutive silent ovulations have been recorded on a number of occasions (Hunter, 1964; Hunter \& Lishman, 1967a, b).

The first of the two uni-cornual ewes to be observed in this laboratory, a Merino which had been recorded previously as having lambed, was found at laparotomy to have no left uterine horn and a large but pale CL in the left ovary. From its appearance and from previous experience of observing CL of known ages, and also with the aid of the data of Restall (1964), the GL was estimated to be about 14 days old. It was marked with India ink and the ewe was removed from the original experiment, but remained with a raddled, vasectomized ram in order to observe subsequent cycle lengths. Thereafter, for as long as possible, between each oestrous period further laparotomies were performed and the status of the ovaries was noted.

The ewe exhibited oestrus the day after the first laparotomy. At the subsequent laparotomy, the previously marked cL had regressed and the ewe had ovulated again in the left ovary. During the next 3 months, a further four oestrous periods were recorded and on every occasion the ewe was found to have ovulated only in the left ovary, usually once, but two ovulations occurred at the fourth oestrus. India ink was used twice to mark the new CL, but it seemed wiser as ovulation in the left ovary persisted, to identify the position of each CL by means of a description. It was clear that a fresh ovulation was associated with each oestrous period. Between these five oestrous periods, three cycle lengths of 19 and one of 20 days were recorded. By this time, observation of the ovaries was becoming difficult due to adhesions. Furthermore, the right ovary had remained largely inactive throughout the period of observation, only one or two small follicles being noted on it at each laparotomy, so that the possibility of recording a cycle length associated with an ovulation in the right ovary seemed to be remote. Regular laparotomies and observations of oestrus were therefore discontinued. The ewe was later killed 16 days after an oestrous period and at autopsy the right ovary was again seen to be inactive and two cL were found in the left ovary. These were approximately $8 \mathrm{~mm}$ in diameter and on dissection were found to weigh 396 and $458 \mathrm{mg}$. They were therefore about the normal size for cL of this age.

The second of the two uni-cornual ewes, a German Merino, was discovered during an experiment in which ovulation rates were being determined by means of laparotomy. Following the synchronization of oestrus by means of intravaginal progestagen-impregnated sponges, this ewe was the first of ninety ewes to come into oestrus. At laparotomy a week later, the absent left horn was discovered and two ovulations in the left ovary were noted. The ewe subsequently returned to oestrus twice and at a second laparotomy between these two occasions, two fresh CL were found, both in the left ovary. The cycle lengths thus recorded were 17 and 20 days respectively. At autopsy, a cL was found in each ovary, the only occasion in either of these ewes in which one was observed in the right ovary.

Between these two ewes, therefore, a total of six cycle lengths was recorded when the GL were known to be only in the ovary which was contralateral to the single uterine horn. Of these cycles, one was 17 days, three were 19 days and two were 20 days in length. Oestrous cycle lengths in the Merino have previously 
been found to vary considerably, but $76 \%$ of cycles were found to be in the range of 16 to 19 days (Hunter, 1962). Only two of the six cycles described above were outside this range, which does not suggest that the lack of the left uterine horn resulted in any marked increase in the life-span of the CL in the left ovary.

In the uni-cornual ewe described by McCracken \& Caldwell (1969), both oviducts were reported as being present. In the two ewes discussed here, however, the left oviducts and uterine horns were both absent.

Thanks are due to Dr G. N. Louw for his comments on the manuscript.

\section{REFERENCES}

Galdwell, B. V., Rowson, L. E. A., Moor, R.M. \& HAY, M.F. (1969) The utero-ovarian relationship and its possible role in infertility. $\mathcal{F}$. Reprod. Fert., Suppl. 8, 59.

GiNTHER, O. J. (1967) Local utero-ovarian relationships. F. Anim. Sci. 26, 578.

Grant, R. (1933) Occurrence of ovulation without "heat" in the ewe. Nature, Lond. 131, 802.

Hunter, G. L. (1962) Observations on oestrus in Merinos. Proc. S. Afr. Soc. Anim. Prod. 1, 67.

Huntre, G. L. (1964) The effects of season and mating on oestrus and fertility in the ewe. Proc. S. Afr. Soc. Anim. Prod. 3, 196.

Hunter, G. L. \& Lishman, A. W. (1967a) Effect of the ram early in the breeding season on the incidence of ovulation and oestrus in sheep. Proc. S. Afr. Soc. Anim. Prod. 6, 199.

Hunter, G. L. \& Lishman, A. W. (1967b) Post-partum ovulation and oestrus in spring-lambing ewes. 7. Reprod. Fert. 14, 473.

INSKEeP, E. K. \& BUtcheR, R. L. (1966) Local component of utero-ovarian relationships in the ewe. 7. Anim. Sci. 25, 1164 .

MCGRACKEN, J. A. \& CALDWELL, B. V. (1969) Corpus luteum maintenance in a ewe with one congenitally absent uterine horn. 7. Reprod. Fert. $20,139$.

Melampy, R. M. \& Anderson, L. L. (1968) Role of the uterus in corpus luteum function. F. Anim. Sci., Suppl. 1, 77.

Moor, R. M. \& Rowson, L. E. A. (1966) Local uterine mechanisms affecting luteal function in the sheep. F. Reprod. Fert. 11, 307.

Nalbandov, A. V. \& Cook, B. (1968) Reproduction. A. Rev. Physiol. 30, 245.

Restall, B. J. (1964) The growth and retrogression of the corpus luteum in the ewe. Aust. Fnl exp. Agric. $\mathcal{E}$ Anim. Husb. 4, 274. 